\title{
Usage of plant protection products, costs and profitability of reducing weed infestation at an individual farm in the years 2004-2013
}

\author{
Zużycie środków ochrony roślin oraz koszty i opłacalność redukowania \\ stanu zachwaszczenia w gospodarstwie indywidualnym w latach 2004-2013
}

\author{
Maria Golinowska ${ }^{1}$, Michał Kruszyński $^{1}$, Tomasz Wiciak $^{2}$, Krzysztof Rutkiewicz $^{1}$
}

\begin{abstract}
Summary
In the years 2004-2013, the field experiments were carried out at an individual farm, located in Opolskie Province. The research aimed at the estimation of expenditure on chemical control of weed infestation in cultivation of cereals, oilseed rape, sugar beet and potatoes, as well as estimation of profitability of chemical treatments applied for this purpose. The expenditure on chemical weed control consisted of the use of herbicides in $\mathrm{kg} / \mathrm{ha}$, in PLN, $\mathrm{kg}$ of active substance, costs of performing weed control for several times. The profitability of plant protection treatment was expressed by the coverage rate. The research materials came from the farm and were subjected to vertical analysis, analysis of unit cost, as well as statistical methods. The research proved high diversity of expenditure on chemical weed control in the examined plant cultivation. Especially high costs of chemical weed control characterized cultivation of sugar beet and oilseed rape.
\end{abstract}

Key words: weed control costs; profitability; individual farm; usage of plant protection

\section{Streszczenie}

W gospodarstwie indywidualnym położonym w województwie opolskim w latach 2004-2013 prowadzono badania, których celem było określenie nakładów na chemiczne redukowanie stanu zachwaszczenia w uprawie: zbóż, rzepaku ozimego, buraków cukrowych i ziemniaków oraz opłacalności przeprowadzenia zabiegów chemicznych redukowania chwastów. Nakłady na ochronę chemiczną dotyczą zużycia herbicydów w kg/ha, w PLN oraz kg substancji czynnej, kosztów przeprowadzania zabiegu chwastobójczego, krotności zabiegu. Opłacalność zabiegu ochronnego przedstawiono za pomocą wskaźnika pokrycia kosztów. Materiały do badań pochodziły z gospodarstwa rolnego, a opracowano je metodą analizy ekonomicznej pionowej, kosztów jednostkowych oraz metodami statystycznymi. Badania wykazały duże zróżnicowanie nakładów na chemiczne redukowanie zachwaszczenia w analizowanych uprawach. Wysokimi kosztami chemicznego zwalczania chwastów charakteryzowała się uprawa buraków cukrowych i rzepaku ozimego.

Słowa kluczowe: koszty zwalczania chwastów; opłacalność; gospodarstwo indywidualne; zużycie środków ochrony roślin

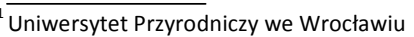

Katedra Ekonomiki i Organizacji Rolnictwa

Instytut Nauk Ekonomicznych i Społecznych

Zakład Ekonomiki Rolnictwa, Ochrony Roślin i Środowiska

Pl. Grunwaldzki 24A, 50-363 Wrocław

maria.golinowska@up.wroc.pl

${ }^{2}$ Zespół Szkół Rolniczych w Namysłowie

Puławskiego 3, 46-100 Namysłów
} 


\section{Wstęp / Introduction}

Redukowanie stanu zachwaszczenia jest ważnym elementem procesu produkcji w każdej uprawie. Powierzchnia robocza redukowania stanu zachwaszczenia w zadaniach rzeczowych chemicznej ochrony roślin stanowi ponad 50\% powierzchni roboczej zwalczania agrofagów (Golinowska 2009). Powierzchnia robocza zwalczania agrofagów wynosi około $23 \mathrm{mln}$ ha. Powierzchnia robocza zwalczania chwastów w ostatnim trzydziestoleciu bardzo szybko przyrasta. Średnio w roku powierzchnia redukowania ta przyrastała o 180 tys. ha. Zabiegi redukujące stan zachwaszczenia wykonuje się od wielu lat na powierzchni powyżej $10 \mathrm{mln}$ ha.

W latach 2005-2012 w Polsce sprzedaż herbicydów w kg masy systematycznie wzrastała i wahała się od 24455182 kg w 2005 r. do 38747999 kg w 2012 r. Przyrost sprzedaży herbicydów wynosił w tym okresie $14242817 \mathrm{~kg}$. Średnioroczna sprzedaż środków chwastobójczych w latach 2005-2012 wynosiła 2 mln kg. Przeliczając masę towarową na substancję czynną (s.cz.) sprzedaż herbicydów w tym okresie wzrosła z $8375016 \mathrm{~kg}$ s.cz. w 2005 r. do 12050132 kg s.cz. w 2012 r. i był to wzrost o $3675016 \mathrm{~kg}$ s.cz. ( Golinowska 2014).

Tabela 1. Udział herbicydów w sprzedaży środków ochrony roślin w Polsce w latach 2005-2012 [\%]

Table 1. The share of herbicides in the sale of plant protection products in Poland in the years 2005-2012 [\%]

\begin{tabular}{c|c|c}
\hline \multirow{2}{*}{ Rok - Year } & \multicolumn{2}{|c}{$\begin{array}{c}\text { \% herbicydów } \\
\text { \% of herbicides }\end{array}$} \\
\cline { 2 - 3 } & $\begin{array}{c}\text { w masie towarowej } \\
\text { in stock weight }\end{array}$ & $\begin{array}{c}\text { w substancji czynnej } \\
\text { in active substance }\end{array}$ \\
\hline 2005 & 59,0 & 52,2 \\
2006 & 58,6 & 54,5 \\
2007 & 64,2 & 58,4 \\
2008 & 59,5 & 53,0 \\
2009 & 56,3 & 51,5 \\
2010 & 58,6 & 53,9 \\
2011 & 61,2 & 56,9 \\
2012 & 62,7 & 55,0 \\
\hline
\end{tabular}

Źródło: Obliczenia własne na podstawie www.bip.minrol.gov.pl Source: Own calculation based on www.bip.minrol.gov.pl

W tabeli 1. przestawiono udział herbicydów w sprzedaży środków ochrony roślin w masie towarowej oraz w s.cz. Udział herbicydów w sprzedaży jest wysoki i wynosił ponad $50 \%$ osiągając w ostatnim roku analizy $62,7 \%$ w masie towarowej i 55\% w s.cz. Dwa wskaźniki związane z nakładami na chemiczne redukowanie chwastów takie, jak powierzchnia robocza zwalczania chwastów i sprzedaż pestycydów świadczą o właściwej strategii zapobiegania zachwaszczeniu agrocenoz. Strategia ta uwzględnia programy decyzyjne, zalecane na podstawie znajomości progów szkodliwości poszczególnych chwastów. W tym kontekście ważna jest szczególnie znajomość funkcjonowania banku nasion chwastów w glebie (WójcikWojkowiak 1987; Bochenek 2000). Wykorzystanie progów szkodliwości $\mathrm{w}$ procesie produkcji upraw (w agrotechnice) stanowić powinno ważny element integrowanych metod ochrony roślin przed agrofagami (Rola i wsp. 2013). Nowoczesne strategie zwalczania chwastów powinny opierać się na przewidywaniu ich pojawienia się w agrocenozach w zależności od czynników agrotechnicznych i meteorologicznych (Grudy 2003).

Chwasty są silnymi konkurentami roślin uprawnych o takie czynniki, jak: światło, wodę i składniki pokarmowe z gleby. Na plantacjach bardzo zachwaszczonych straty makroskładników dochodzą nawet do 70\% (Zimdahl 1980). Ostatecznym skutkiem konkurencji jest obniżenie plonów roślin uprawnych. Na wielkość obniżenia plonów wpływa wiele czynników, a najważniejszym jest stopień zachwaszczenia plantacji (Banaszkiewicz 2005). Wyeliminowanie (zmniejszenie stanu zachwaszczenia) chwastów z upraw polega na racjonalnym ograniczeniu ich konkurencji za pomocą różnych metod odchwaszczania.

Celem badań była wieloletnia analiza kosztów i opłacalności redukowania stanu zachwaszczenia w gospodarstwie indywidualnym w pszenicy ozimej, rzepaku ozimego, burakach cukrowych i ziemniakach.

\section{Materiały i metody / Materials and methods}

Do badań w sposób celowy wybrano gospodarstwo indywidualne, które w latach 2004-2013 prowadziło działalność gospodarczą stosując w procesie produkcji roślinnej redukowanie zachwaszczenia metodą chemiczną. Materiał do badań pochodził z zapisów księgowych ewidencjonowanych w księdze przychodów i rozchodów przez właściciela gospodarstwa dla potrzeb własnych.

Materiał źródłowy opracowano za pomocą analizy ekonomicznej pionowej i porównawczej oraz syntetycznej $\mathrm{I}^{0}$ (Kopeć 1983). Koszty redukowania stanu zachwaszczenia określono zgodnie $\mathrm{z}$ metodologią przedstawioną na rysunku 1. (Golinowska 2012), a opłacalność redukowania stanu zachwaszczenia przedstawiono za pomocą orientacyjnych wskaźników opłacalności $E_{1}$ i $E_{2}$ (Mierzejewska 1989; Golinowska 1992, 2002, 2009). Pierwszy wskaźnik mówi o ilości dt produktu chronionego pokrywającego zabieg ochronny, a drugi o procencie zbioru, jaki należy przeznaczyć na chemiczną ochronę roślin.

Nakłady na chemiczną ochronę roślin w badanym gospodarstwie przedstawiono za pomocą:

- zużycia środków ochrony roślin w uprawach pszenicy ozimej, rzepaku ozimego, buraków cukrowych i ziemniaków w kg s.cz. na 1 ha i w PLN na 1 ha oraz za pomocą struktury zużycia środków ochrony roślin,

- krotności zabiegów,

- kosztów redukowania stanu zachwaszczenia. 


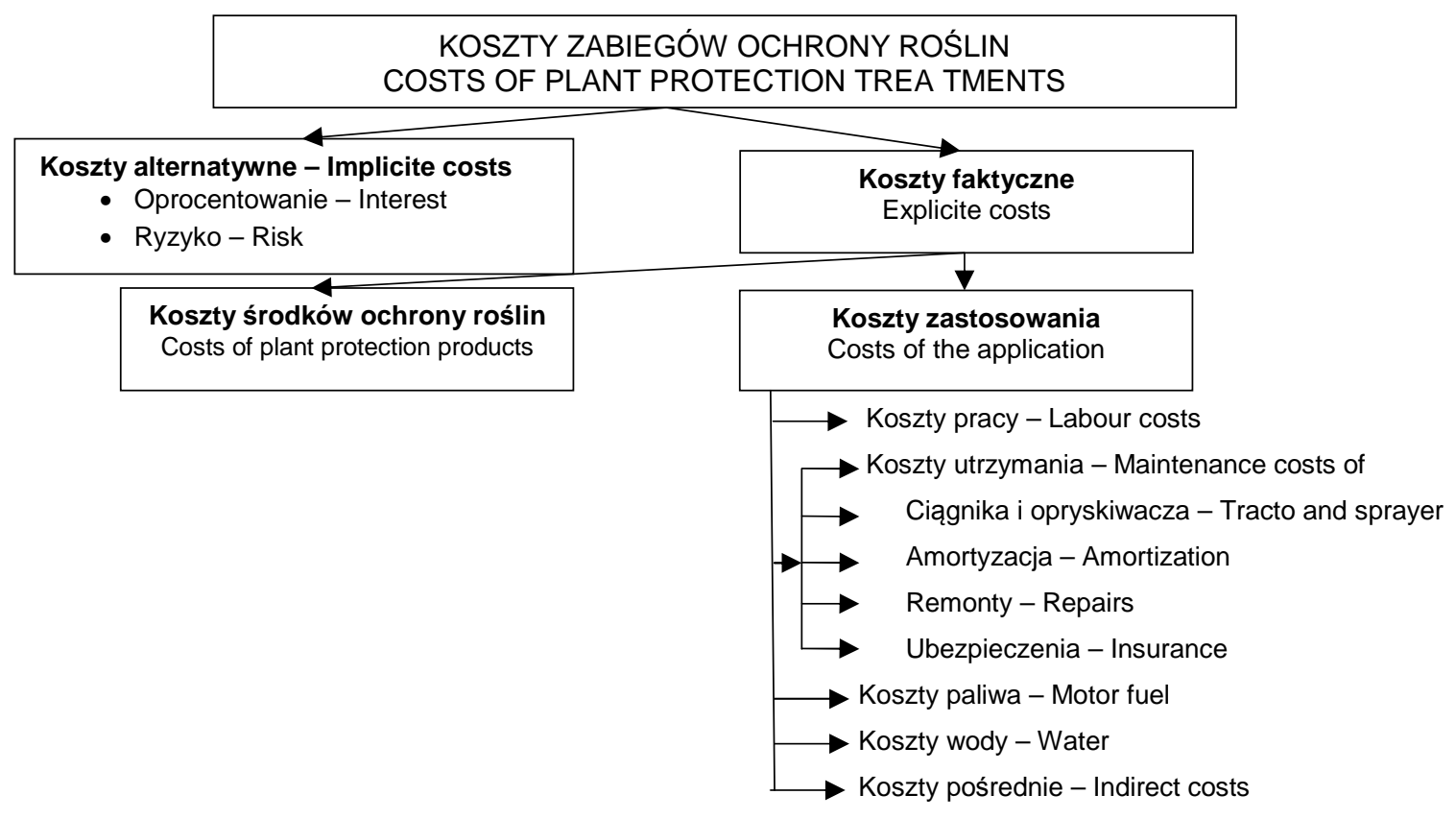

Rys. 1. Koszty zabiegów ochrony roślin

Fig. 1. Costs of plant protection treatments

\section{Wyniki i dyskusja / Results and discussion}

Badane gospodarstwo znajduje się we wsi Kowalowice w gminie miejsko-wiejskiej Namysłów, która to gmina posiada powierzchnię użytków rolnych (UR) wynoszącą 18191 ha i stanowi to $62,7 \%$ powierzchni ogólnej gminy, $26,3 \%$ to lasy i grunty orne oraz $11 \%$ to grunty pod drogami i wodami. Użytki rolne powiatu Namysłów wynoszą 67 739,2 ha i w 70\% należą do klasy III i IV. W powiecie działalność produkcyjną rolniczą prowadzi 3777 gospodarstw, $\mathrm{z}$ tego w gminie miejsko-wiejskiej Namysłów 44,2\%. Średnia powierzchnia gospodarstwa $\mathrm{w}$ powiecie, jak $\mathrm{i} \mathrm{w}$ gminie jest podobna $\mathrm{i} \mathrm{w}$ powiecie wynosi 17,93 ha, a w gminie 17,25 ha. Organizacja produkcji roślinnej wyrażona za pomocą struktury zasiewów w badanej gminie w 2011 r. była następująca: 56\% stanowiły zboża, $28 \%$ rzepak ozimy, 5\% okopowe i $12 \%$ inne. Efekty produkcyjne wyrażone za pomocą uzyskiwanych plonów na Opolszczyźnie są wysokie.

Badane gospodarstwo indywidualne w latach 20042013 zwiększyło powierzchnię swego gospodarstwa o $100 \%$, co wynikało z zakupu, jak i z dzierżawy (tab. 2). Zmianie uległa struktura UR (zlikwidowano użytki zielone $\mathrm{z}$ chwilą likwidacji stada bydła) oraz zmieniła się struktura zasiewów. W 2013 r. system gospodarczy z hodowlanookopowego uległ zmianie na roślinny. Przez zmiany organizacyjne takie, jak: likwidacja stada bydła oraz zmiany w strukturze zasiewów, intensywność organizacji gospodarstwa zmalała o 50\% (z 384,9 pkt. do 184,1 pkt.).

W procesie produkcji roślinnej jako zabieg pielęgnacyjny badane gospodarstwo stosuje chemiczną ochronę roślin. Zabiegi chemiczne wykonywane były opryskiwaczem o pojemności 6001 i szerokości roboczej $12 \mathrm{~m}$. Opryskiwacz posiada atest. W tabeli 3. przedstawiono zużycie środków ochrony roślin w badanych latach i analizowanych uprawach. Najwięcej s.cz. na 1 ha w ostatnich latach, stoso- wano w burakach cukrowych, ziemniakach, a w zbożach i rzepaku ozimym użyto od 2,51 do 2,6 kg s.cz./ha. W ujęciu wartościowym (w PLN/ha) koszty środków ochrony roślin w analizowanych latach wzrastały. Dla pszenicy wzrost był sześciokrotny (od 142,3 do 880,8 PLN/ha), dla buraków cukrowych zwyżka kosztów była 2,5-krotna, a w rzepaku ozimym odnotowano $20 \%$ wzrost (tab. 3). Głównym powodem wzrostu tego wskaźnika była zmiana struktury asortymentowej środków produkcji. W tabeli 4. przedstawiono udział herbicydów w zużytych środkach ochrony roślin. W pierwszym roku analizy w uprawie pszenicy wynosił on zaledwie $12,4 \%$ i w kolejnych latach systematycznie wzrastał osiągając w 2013 r. ponad czterokrotny wzrost. W uprawie rzepaku ozimego również wzrastał udział herbicydów, natomiast w uprawie buraków cukrowych udział herbicydów zmniejszył się o 20\%, a w ziemniakach przez cały czas wynosił $35,2 \%$. W kosztach zużytych pestycydów, herbicydy stanowiły we wszystkich uprawach za wyjątkiem pierwszych lat, ponad $50 \%$ i oznacza to znaczący koszt zastosowania herbicydów.

Krotność wykonywania zabiegów chemicznych, to następna miara określająca intensywność nakładów na zabiegi ochronne. W tabeli 5. przedstawiono krotność zabiegów w analizowanym gospodarstwie na przestrzeni lat, według upraw $\mathrm{z}$ wyodrębnieniem zabiegów chwastobójczych. Największą krotnością wynoszącą 6 (6 razy wykonywano zabiegi) charakteryzowała się uprawa buraków cukrowych, w tym redukujące stan zachwaszczenia stanowiły 50\% liczby zabiegów. Do roku 2006 w uprawie buraków cukrowych wykonywano tylko zabiegi chwastobójcze. W uprawie rzepaku ozimego około 50\% zabiegów stanowiły zabiegi redukujące chwasty. W uprawie pszenicy ozimej w latach 2004-2013 wykonywano tylko jeden zabieg chwastobójczy, a w ziemniakach dwa zabiegi z pięciu przeznaczone były redukowaniu stanu zachwaszczenia. 


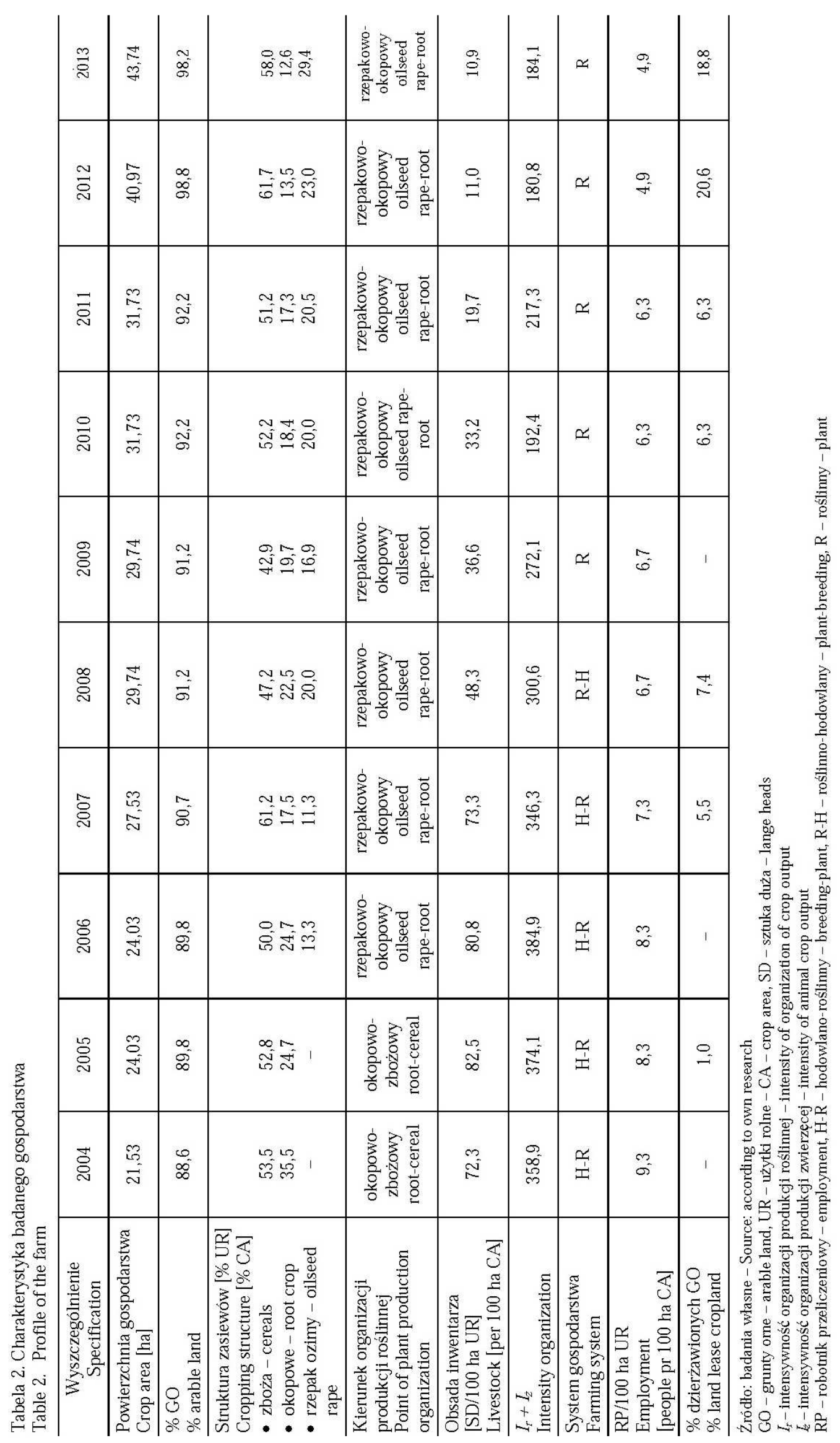


Tabela 3. Zużycie środków ochrony roślin w s.cz. w badanym gospodarstwie

Table 3. Use of active substance (a.s.) of plant protection products at the farm

\begin{tabular}{l|c|c|c|c|c|c|c|c|c|c}
\hline Wyszczególnienie - Specification & 2004 & 2005 & 2006 & 2007 & 2008 & 2009 & 2010 & 2011 & 2012 & 2013 \\
\hline & \multicolumn{10}{|c|}{ kg substancji czynnej/1 ha UR - kg active substance per ha CA } \\
\hline Pszenica ozima - Winter wheat & 1,45 & 1,80 & 3,21 & 3,76 & 3,80 & 3,80 & 3,80 & 2,59 & 2,60 & 2,60 \\
Rzepak ozimy - Oilseed rape & - & - & - & 3,55 & 3,55 & 3,55 & 3,55 & 2,51 & 2,51 & 2,51 \\
Buraki cukrowe - Sugar beet & 1,64 & 1,64 & 1,64 & 2,21 & 2,21 & 4,24 & 4,26 & 4,24 & 4,24 & 4,24 \\
Ziemniaki - Potatoes & 3,26 & 3,26 & 3,26 & 3,26 & 3,26 & 3,26 & 3,26 & 3,26 & 3,26 & 3,26 \\
\hline & \multicolumn{10}{c}{ PLN/1 ha UR - PLN per ha CA } \\
\hline Pszenica ozima - Winter wheat & 142,3 & 212,4 & 600,8 & 628,2 & 642,3 & 661,6 & 666,0 & 823,6 & 880,8 & 830,3 \\
Rzepak ozimy - Oilseed rape & - & - & - & 651,0 & 817,0 & 808,0 & 831,0 & 742,1 & 748,2 & 786,2 \\
Buraki cukrowe - Sugar beet & 370,0 & 573,6 & 370,8 & 506,5 & 446,5 & 514,0 & 763,3 & 872,4 & 872,4 & 872,4 \\
Ziemniaki - Potatoes & 490,6 & 492,1 & 495,1 & 497,2 & 501,6 & 503,1 & 507,2 & 509,1 & 515,2 & 529,5 \\
\hline
\end{tabular}

Źródło: badania własne - Source: according to own research

UR - użytki rolne - CA - crop area

Tabela 4. Zużycie herbicydów w analizowanym gospodarstwie w stosunku do zużycia środków ochrony roślin

Table 4. Use of herbicides in correlation to the usage of plant protection products at the farm

\begin{tabular}{|c|c|c|c|c|c|c|c|c|}
\hline \multirow{3}{*}{$\begin{array}{l}\text { Lata } \\
\text { Years }\end{array}$} & \multicolumn{8}{|c|}{ \% herbicydów - \% herbicides } \\
\hline & \multicolumn{4}{|c|}{ w substancji czynnej - in active substance } & \multicolumn{4}{|c|}{ w wartości - in value } \\
\hline & $\begin{array}{c}\text { pszenica } \\
\text { ozima } \\
\text { winter wheat }\end{array}$ & $\begin{array}{c}\text { rzepak } \\
\text { ozimy } \\
\text { oilseed rape }\end{array}$ & $\begin{array}{c}\text { buraki } \\
\text { cukrowe } \\
\text { sugar beet }\end{array}$ & $\begin{array}{l}\text { ziemniaki } \\
\text { potatoes }\end{array}$ & $\begin{array}{c}\text { pszenica } \\
\text { ozima } \\
\text { winter wheat }\end{array}$ & $\begin{array}{l}\text { rzepak ozimy } \\
\text { oilseed rape }\end{array}$ & $\begin{array}{c}\text { buraki } \\
\text { cukrowe } \\
\text { sugar beet }\end{array}$ & $\begin{array}{c}\text { ziemniaki } \\
\text { potatoes }\end{array}$ \\
\hline 2004 & 14,2 & - & 100,0 & 35,2 & 26,6 & - & 100,0 & 24,8 \\
\hline 2005 & 10,0 & - & 100,0 & 35,2 & 17,9 & - & 100,0 & 24,6 \\
\hline 2006 & 46,7 & - & 100,0 & 35,2 & 71,5 & - & 100,0 & 24,0 \\
\hline 2007 & 39,8 & 59,7 & 88,7 & 35,2 & 69,7 & 52,6 & 82,9 & 23,9 \\
\hline 2008 & 39,8 & 59,7 & 88,7 & 35,2 & 69,8 & 67,1 & 79,8 & 23,8 \\
\hline 2009 & 40,1 & 59,7 & 88,7 & 35,2 & 69,6 & 65,9 & 84,2 & 23,5 \\
\hline 2010 & 40,1 & 71,7 & 79,2 & 35,2 & 68,9 & 64,0 & 75,8 & 23,3 \\
\hline 2011 & 57,6 & 71,7 & 79,2 & 35,2 & 53,7 & 55,1 & 80,0 & 23,1 \\
\hline 2012 & 57,6 & 71,7 & 79,2 & 35,2 & 50,3 & 54,7 & 80,0 & 23,0 \\
\hline
\end{tabular}

Źródło: badania własne - Source: according to own research

Tabela 5. Krotność zabiegów ochronnych w analizowanym gospodarstwie, w tym chwastobójczych

Table 5. Multiplicity of treatments at the farm, including herbicides

\begin{tabular}{|c|c|c|c|c|c|c|c|c|}
\hline \multirow{5}{*}{$\begin{array}{l}\text { Lata } \\
\text { Years }\end{array}$} & \multicolumn{8}{|c|}{ Uprawa - Cultivation } \\
\hline & \multicolumn{2}{|c|}{$\begin{array}{c}\text { pszenica ozima } \\
\text { winter wheat }\end{array}$} & \multicolumn{2}{|c|}{$\begin{array}{l}\text { rzepak ozimy } \\
\text { oilseed rape }\end{array}$} & \multicolumn{2}{|c|}{$\begin{array}{c}\text { buraki cukrowe } \\
\text { sugar beet }\end{array}$} & \multicolumn{2}{|c|}{$\begin{array}{c}\text { ziemniaki } \\
\text { potatoes }\end{array}$} \\
\hline & \multicolumn{8}{|c|}{ zabiegi chemiczne - chemical treatments } \\
\hline & $\begin{array}{l}\text { ogółem } \\
\text { total }\end{array}$ & $\begin{array}{c}\text { w tym } \\
\text { chwastobójcze } \\
\text { including } \\
\text { herbicides }\end{array}$ & $\begin{array}{l}\text { ogółem } \\
\text { total }\end{array}$ & $\begin{array}{c}\text { w tym } \\
\text { chwastobójcze } \\
\text { including } \\
\text { herbicides }\end{array}$ & $\begin{array}{l}\text { ogółem } \\
\text { total }\end{array}$ & $\begin{array}{c}\text { w tym } \\
\text { chwastobójcze } \\
\text { including } \\
\text { herbicides }\end{array}$ & $\begin{array}{l}\text { ogółem } \\
\text { total }\end{array}$ & $\begin{array}{c}\text { w tym } \\
\text { chwastobójcze } \\
\text { including } \\
\text { herbicides }\end{array}$ \\
\hline & \multicolumn{8}{|c|}{ liczba zabiegów - number of treatments } \\
\hline 2004 & 2 & 1 & - & - & 4 & 4 & 5 & 2 \\
\hline 2005 & 3 & 1 & - & - & 4 & 4 & 5 & 2 \\
\hline 2006 & 3 & 1 & - & - & 4 & 4 & 5 & 2 \\
\hline 2007 & 3 & 1 & 5 & 3 & 4 & 3 & 5 & 2 \\
\hline 2008 & 3 & 1 & 5 & 3 & 4 & 3 & 5 & 2 \\
\hline 2010 & 3 & 1 & 5 & 2 & 4 & 3 & 5 & 2 \\
\hline 2011 & 3 & 1 & 5 & 2 & 6 & 3 & 5 & 2 \\
\hline 2012 & 3 & 1 & 5 & 2 & 6 & 3 & 5 & 2 \\
\hline 2013 & 3 & 1 & 5 & 2 & 6 & 3 & 5 & 2 \\
\hline
\end{tabular}

Źródło: badania własne - Source: according to own research 
Tabela 6. Plony i ceny ziemiopłodów w analizowanym gospodarstwie

Table 6. Productivity and prices of agricultural products

\begin{tabular}{c|c|c|c|c|c|c|c|c}
\hline \multirow{2}{*}{$\begin{array}{c}\text { Lata } \\
\text { Years }\end{array}$} & \multicolumn{4}{|c|}{ Plony - Yields [t/ha] } & \multicolumn{4}{c}{ Ceny - Prices [PLN/t] } \\
\cline { 2 - 9 } & $\begin{array}{c}\text { pszenica } \\
\text { ozima } \\
\text { winter wheat }\end{array}$ & $\begin{array}{c}\text { buraki } \\
\text { cukrowe } \\
\text { sugar beet }\end{array}$ & $\begin{array}{c}\text { rzepak } \\
\text { ozimy } \\
\text { oilseed rape }\end{array}$ & $\begin{array}{c}\text { ziemniaki } \\
\text { potatoes }\end{array}$ & $\begin{array}{c}\text { pszenica } \\
\text { wheat }\end{array}$ & $\begin{array}{c}\text { buraki } \\
\text { cukrowe } \\
\text { sugar beet }\end{array}$ & $\begin{array}{c}\text { rzepak ozimy } \\
\text { oilseed rape }\end{array}$ & $\begin{array}{c}\text { ziemniaki } \\
\text { potatoes }\end{array}$ \\
\hline 2004 & 4,9 & 55 & - & 18 & 430 & 120 & - & 340 \\
2005 & 5,1 & 58 & - & 17 & 370 & 125 & - & 400 \\
2006 & 4,8 & 62 & - & 22 & 470 & 130 & - & 500 \\
2007 & 6,0 & 57 & 4,3 & 21 & 680 & 110 & 840 & 1000 \\
2008 & 5,3 & 40 & 3,7 & 16 & 650 & 114 & 930 & 700 \\
2009 & 6,8 & 65 & 3,8 & 19 & 470 & 118 & 1050 & 500 \\
2010 & 6,1 & 63 & 3,2 & 20 & 680 & 116 & 1250 & 500 \\
2011 & 6,7 & 70 & 3,5 & 22 & 800 & 119 & 1750 & 400 \\
2012 & 5,5 & 78 & 2,7 & 27 & 950 & 127 & 1840 & 350 \\
2013 & 7,2 & 67 & 4,0 & 15 & 775 & 117 & 1450 & 1000 \\
\hline
\end{tabular}

Źródło: badania własne - Source: according to own research

Opłacalność zabiegów redukowania stanu zachwaszczenia wyrażona za pomocą orientacyjnych wskaźników opłacalności $E_{1}$ i $E_{2}$ została przestawiona w tabeli 7 . Na kształtowanie się tych wskaźników miały wpływ: ceny produktu chronionego, koszty zabiegów ochronnych oraz uzyskiwany plon upraw chronionych. Ceny sprzedaży produktów chronionych oraz uzyskiwane plony badane gospodarstwo uzyskiwało na dobrym poziomie (tab. 6).

Tabela 7. Opłacalność zabiegów redukowania stanu zachwaszczenia $\mathrm{w}$ analizowanym gospodarstwie

Table 7. Profitability of herbicide treatments at the farm

\begin{tabular}{c|c|c|c|c|c|c|c|c}
\hline \multirow{2}{*}{$\begin{array}{c}\text { Lata } \\
\text { Years }\end{array}$} & $\begin{array}{c}\text { Pszenica } \\
\text { ozima } \\
\text { Winter } \\
\text { wheat }\end{array}$ & \multicolumn{2}{c|}{$\begin{array}{c}\text { Buraki } \\
\text { cukrowe } \\
\text { Sugar beet }\end{array}$} & \multicolumn{2}{c|}{$\begin{array}{c}\text { Rzepak } \\
\text { ozimy } \\
\text { Oilseed } \\
\text { rape }\end{array}$} & \multicolumn{2}{|c}{$\begin{array}{c}\text { Ziemniaki } \\
\text { Potatoes }\end{array}$} \\
\cline { 2 - 9 } & $\begin{array}{c}E_{1} \\
{[\mathrm{dt}]}\end{array}$ & $\begin{array}{c}E_{2} \\
{[\%]}\end{array}$ & $\begin{array}{c}E_{1} \\
{[\mathrm{dt}]}\end{array}$ & $\begin{array}{c}E_{2} \\
{[\%]}\end{array}$ & $\begin{array}{c}E_{1} \\
{[\mathrm{dt}]}\end{array}$ & $\begin{array}{c}E_{2} \\
{[\%]}\end{array}$ & $\begin{array}{c}E_{1} \\
{[\mathrm{dt}]}\end{array}$ & $\begin{array}{c}E_{2} \\
{[\%]}\end{array}$ \\
\hline 2004 & 1,3 & 2,7 & - & - & 37,5 & 6,8 & 5,1 & 28,0 \\
2005 & 1,6 & 3,1 & - & - & 37,4 & 6,5 & 4,2 & 25,0 \\
2006 & 1,4 & 2,9 & - & - & 35,9 & 6,8 & 3,6 & 17,0 \\
2007 & 6,4 & 10,7 & 4,9 & 12,3 & 50,2 & 8,8 & 1,8 & 9,0 \\
2008 & 7,1 & 13,4 & 5,5 & 15,0 & 43,7 & 10,9 & 2,5 & 15,0 \\
2009 & 7,2 & 15,1 & 5,1 & 13,4 & 43,5 & 10,3 & 5,0 & 26,0 \\
2010 & 7,1 & 11,7 & 4,3 & 13,5 & 41,6 & 6,6 & 3,5 & 18,0 \\
2011 & 5,8 & 8,7 & 2,6 & 7,4 & 44,3 & 6,3 & 4,4 & 20,0 \\
2012 & 4,9 & 9,2 & 2,5 & 9,2 & 41,8 & 5,3 & 4,9 & 18,0 \\
2013 & 6,0 & 8,3 & 3,2 & 8,0 & 53,7 & 8,0 & 1,8 & 11,4 \\
\hline
\end{tabular}

Źródło: badania własne - Source: according to own research

$E_{1}, E_{2}$ - wskaźnik opłacalności - profitability index

W uprawie pszenicy wskaźnik pokrycia kosztów $E_{1}$ w latach 2004-2013 wahał się od 1,3 o 7,2. Oznacza to, że na koszty faktyczne chemicznych zabiegów ochrony roślin należało przeznaczyć w 2004 r. 1,3 dt pszenicy, a stanowiło to $2,7 \%$ zbioru tej uprawy. W pierwszych trzech latach analizy opłacalność redukowania stanu zachwaszczenia była najwyższa, gdyż stosowano środki o niższej zawartości s.cz. i tym samym tańsze. W następnych latach wskaźniki kształtowały się na podobnym poziomie, za wyjątkiem roku 2009, gdzie wskaźniki $E_{1}$ i $E_{2}$ osiągnęły najbardziej niekorzystne wyniki (analogicznie: 7,2 dt, 15,1\%). Główną przyczyną takiego stanu rzeczy była niska cena skupu (470 PLN). W uprawie rzepaku ozimego w końcowych latach analizy opłacalność redukowania chwastów poprawiła się w stosunku do roku 2007 dwukrotnie. W uprawie buraków cukrowych na pokrycie kosztów faktycznych redukowania chwastów należało przeznaczyć od 5,3\% w 2012 r. do 10,9\% zbioru, a w uprawie ziemniaków wskaźnik $E_{2}$ wynosił 9,0-26,0\%. Najkorzystniejsze wskaźniki we wszystkich uprawach gospodarstwo uzyskało w 2007 r.

Herbicydy stosowane do chemicznego redukowania chwastów były dopuszczone do obrotu i stosowano je zgodnie z zaleceniami.

\section{Podsumowanie / Summation}

Przeprowadzone badania dotyczące zużycia środków ochrony roślin oraz kosztów i opłacalności redukowania stanu zachwaszczenia w latach 2004-2013 wykazały, że:

1. Struktura organizacji gospodarstwa wyrażona za pomocą systemu gospodarczego uległa zmianie z systemu hodowlano-okopowego bardzo wysoko intensywnego na roślinny (rzepakowo-zbożowy) ekstensywny.

2. Zmieniła się struktura zasiewów, zmalał udział roślin okopowych na korzyść rzepaku ozimego i zbóż, a w produkcji zwierzęcej zmalała obsada inwentarza żywego z 82,5 do 10,9 SD/100 ha UR. Zmiany te miały istotny wpływ na zużycie środków ochrony roślin w analizowanych uprawach.

3. Nakłady na chemiczne redukowanie stanu zachwaszczenia zajmowały znaczący udział w zużyciu pestycydów w s.cz., jak i w kosztach zużytych pestycydów.

4. Najwyższą krotność (liczbę) zabiegów chwastobójczych wykonywano w uprawie buraków cukrowych, w zbożach i rzepaku ozimym zazwyczaj wykonywano po 1 zabiegu, a w ziemniakach 2.

5. Opłacalność chemicznego redukowania stanu zachwaszczenia była zróżnicowana zarówno na przestrzeni 
lat, jak i pomiędzy uprawami. Na kształtowanie się wskaźników $E_{1}$ i $E_{2}$ decydujący wpływ miały ceny zbytu produktów chronionych, wysokość plonów oraz koszty redukowania stanu zachwaszczenia.
6. Na koszty redukowania stanu zachwaszczenia wpływ miały ceny i dawki stosowanych herbicydów oraz koszty zastosowania herbicydów.

\section{Literatura / References}

Banaszkiewicz T. 2005. Dynamika zachwaszczenia pola w zależności od uprawy wybranych gatunków roślin oraz sposobów zwalczania chwastów w jęczmieniu jarym. Acta Sci. Pol., Agricultura 4 (1): 17-24.

Bochenek A. 2000. Wpływ czynników biotycznych i zabiegów uprawowych na glebowy bank nasion chwastów. Post. Nauk. Rol. 2: 19-29.

Golinowska M. (red.) 1992. Rachunek regresji w ocenie efektywności zwalczania chwastów w rzepaku. s. 131-146. W: „Ekonomika zwalczania chwastów". Wyd. AR Wrocław, 200 ss.

Golinowska M. 2002. Efektywność ochrony roślin w indywidualnych gospodarstwach rolnych południowo-zachodniej Polski. Zesz. Nauk. AR Wrocław 433, 199 ss.

Golinowska M. 2009. Ekonomika ochrony roślin w teorii i praktyce. [Economics of plant protection in theory and practice]. Prog. Plant Prot./Post. Ochr. Roślin 49 (1): 23-33.

Golinowska M. 2012. Koszty integrowanej ochrony roślin. [Costs of integrated plant protection]. Prog. Plant Prot./Post. Ochr. Roślin 52 (3): $521-529$.

Golinowska M. 2014. Tendencje zmian w nakładach na chemiczną ochronę roślin w Polsce po 2004 roku. Prace Nauk. UE Wrocław 20: 88-96.

Grundy A.C. 2003. Predicting weed emergence: a review of approaches and future challenge. Weed Res. 43: 1-11.

Kopeć B. 1987. Intensywność organizacji w rolnictwie polskim w latach 1960-1980. Rocz. Nauk. Rol., S. G., 84 (1): 7-27.

Mierzejewska W. 1989. Rachunek kosztów w ochronie roślin. Zesz. Probl. Post. Nauk Rol. 363: 9-21.

Rola H., Domaradzki K., Kaczmarek S., Kapeluszny J. 2013. Znaczenie progów szkodliwości w integrowanych metodach regulacji zachwaszczenia w zbożach. [Significance of thresholds in integrated methods of weeding regulation in cereals]. Prog. Plant Prot./Post. Ochr. Roślin 53 (1): 96-104.

Wójcik-Wojtkowiak D. 1987. Rola alleopatii w rolniczych ekosystemach. Post. Nauk Rol. 1/2: 37-55.

Zimdahl L.R. 1980. Weed-Crop Competition. A Review. Inter. Plant Prot. Center Oregon State University Corvallis, 197 pp. 